\section{Relation of Student-Teacher Trust with School Well-Being to High School Students}

Meilisa Petrisya Hongwidjojo ; Monika ; Erik Wijaya. Fakultas Psikologi Universitas Tarumanagara e-mail: meylissahongwidjojo@yahoo.com
Journal PSIKODIMENSIA

Volume 17, No. 2, Juli - Desember 2018

ISSN cetak : 1411-6073

ISSN online : 2579-6321

DOI 10.24167/psidim.v17i2.1664

\begin{abstract}
This research is a correlational study using quantitative method of distributing questionnaires to students of class X, XI and XII in X Senior High School in the area of West Jakarta and Y Senior High School in North Jakarta. Student-teacher trust questionnaire refers to Tchannen-Moran's study, while school well-being questionnaire refers to Konu and Rimpelä's study. The research is using purposive sampling technique involving 486 students. The results of the study shows that student-teacher trust has a significant positive relationship with school well-being, so that the higher student-teacher trust, the higher the school well-being. As additional, this study also shows that there is no significant difference in terms of gender.
\end{abstract}

Keywords: Student-Teacher Trust, School Well-Being, Student, School, and Adolescent

\section{PENDAHULUAN}

Remaja atau siswa merupakan salah satu bagian dari lingkungan sekolah. Sekolah merupakan suatu tempat yang memiliki peran besar bagi setiap individu dalam mengenyam pendidikan. Sekolah adalah institusi yang bertanggung jawab untuk pengembangan akademik para siswa serta bertanggung jawab dalam perkembangan sosial dan psikologis mereka.

Salah satu fungsi sekolah yaitu untuk mendidik siswa sesuai dengan kondisi usia siswa dan untuk kebutuhan negara. Selain sebagai lingkungan pendidikan, sekolah juga menjadi tempat tinggal bagi para siswa. Siswa tersebut menghabiskan banyak waktu dengan melakukan berbagai kegiatan dan berinteraksi dengan siswa lain, guru, dan staf sekolah. Sekolah merupakan lingkungan pendidikan sekunder bagi setiap individu, karena lingkungan pendidikan yang pertama dan utama adalah keluarga. Sekolah juga merupakan lingkungan sosial yang berpotensi tempat perkembangan sosial remaja. Selain itu, sekolah merupakan sarana bagi yang berpotensi untuk membentuk kepribadian siswa (Tian dalam Khatimah, 2015).

Keberhasilan dan kebahagiaan, serta perkembangan siswa baik sosial maupun psikologis penting untuk keberhasilan akademis mereka (Marks dalam Eres \& Bilasa, 2016).

School well-being merupakan sebuah konsep yang dikembangkan oleh Konu dan Rimpelä berdasarkan teori well-being yang dikemukakan oleh Allart. Allardt (dalam Konu \& Rimpelä, 2002) berpendapat well-being adalah suatu keadaan yang memungkinkan individu untuk memuaskan kebutuhankebutuhan dasar, yaitu kebutuhan yang bersifat material dan non material. Kemudian school well-being juga terdiri 
dari beberapa dimensi, yaitu (a) having, yaitu dimensi yang berkaitan dengan lingkungan fisik sekolah; (b) loving, yaitu dimensi yang berhubungan dengan lingkungan sosial; (c) being, yaitu dimensi yang terkait dengan pemenuhan diri; dan (d) health, yaitu dimensi yang berhubungan dengan status kesehatan (Konu \& Rimpelä, 2002). Selain itu, Konu dan Rimpelä juga melakukan kajian dari berbagai literatur sosiologis, pendidikan, psikologis, dan peningkatan kesehatan untuk merumuskan konsep school well-being secara menyeluruh (Konu \& Rimpelä, 2002).

Menurut Konu dan Rimpelä (2002), lingkungan sekolah yang berkualitas adalah lingkungan yang sehat dan memperhatikan hubungan sosial yang terjadi dalam lingkungan sekolah, pengembangan diri siswa, serta kesehatan di dalam lingkungan sekolah tersebut. Kepercayaan kepada guru memiliki peran yang signifikan terhadap kualitas kehidupan sekolah dan pembelajaran siswa (Tschannen-Moran, dalam Maele \& Houtte, 2010). Ketika siswa merasa bahwa guru mendukung mereka hal ini_akan meningkatkan keterikatan siswa terhadap sekolah (Hallinan dalam Maele \& Houtte, 2010).

Fenomena yang terjadi di masyarakat menunjukkan terdapat beberapa bentuk diskriminasi sekolah terhadap siswa menurut KPAI, seperti (a) diskriminasi terhadap status orangtua, (b) diskriminasi terhadap disabilitas, (c) diskriminasi pada anak yang mendapat nilai kecil karena tidak mengikuti bimbingan belajar di sekolah, (d) diskriminasi gender, dan (e) diskriminasi terhadap agama ("15 bentuk diskriminasi,” 2013). Selain itu, hasil wawancara terbuka terhadap peserta didik yang dilakukan oleh Hamidah (2018) menunjukkan bahwa hampir semua guru pernah melakukan perilaku diskriminasi_terhadap siswa di kelas.
Fenomena lain yang terjadi di masyarakat berkaitan dengan hubungan antara siswa dengan guru adalah kasus pembunuhan yang dilakukan oleh HI, siswa SMAN 1 Torjun, Sampang, Jawa Timur. Penganiayaan yang dilakukan HI terhadap gurunya bermula ketika guru tersebut menegur HI, namun HI tidak menghiraukan. Guru tersebut memukul HI dan menyiram wajahnya dengan menggunakan cat, sehingga HI kemudian memukul gurunya hingga meninggal (Taufiqurrahman, 2018). Dalam melakukan tindak diskriminatif, seorang guru sering kali meluapkan emosi dengan kata-kata yang kurang baik (bullying). Bullying tersebut dapat merusak kepercayaan dan hubungan yang sedang dijalani (McEvoy, 2014).

Rasa percaya atau trust adalah cara setiap individu untuk saling terikat dan menjalin hubungan (Byrk \& Schneider dalam Basch, 2012). Byrk dan Schneider (dalam Basch, 2012). serta Tschannen-Moran (2014) mengatakan bahwa kepercayaah merupakan agen ikatan yang terjalin antara anggota sekolah yang dapat mendorong pendidikan, keberhasilar|, dan perubahan dalam sekolah (Basch, 2012). Trust terdiri dari beberapa aspek pembentuk, yaitu (a) benevolence (kebajikan) mengacu pada kepercayaan individu terhadap orang lain; (b) honesty (kejujuran) mengacu pada integritas; (c) openness (keterbukaan) berarti seseorang tidak akan menahan informasi atau mendistorsi informasi; (d) reliability (reliabilitas) akan cenderung untuk meyakinkan seseorang dalam memprediksi aksi yang dilakukan oleh orang lain; dan (e) competence (kompetensi) akan cenderung lebih kepada tingkat kemampuan (TschannenMoran, 2014). Seiring terbentuknya hubungan siswa dengan guru di sekolah, sekolah telah menjadi lingkungan yang menciptakan ikatan sosial antara guru dan siswa untuk mengembangkah 
Meilisa Petrisya Hongwidjojo: Relation of Student-Teacher Trust with School Well-Being...

hubungan saling percaya (Putnam, dalam Basch, 2012).

Penelitian sebelumnya menemukan bahwa pada usia remaja tengah dukungan antara teman dan guru memiliki hubungan yang signifikan dengan school well-being (Tian, Liu, Huang, \& Huebner, 2012). Dukungan guru menjadi salah satu prediktor paling siginfikan terhadap school well-being siswa dalam penelitian tersebut. Lee (2007) juga telah melakukan penelitian tentang hubungan the student-teacher trust dan kesuksesan sekolah pada klas menga di Korea. Hasil penelitian yang telah dilakukan yaitu terdapat korelasi positif antara rasa percaya siswa dan guru dengan kesuksesan sekolah (Lee, 2007). Romero (2015) juga telah melakukan penelitian mengenai trust, behavior, and high school outcomes. Penelitian tersebut menunjukkan bahwa rasa percaya memberikan pengaruh besar terhadap achievement (pencapaian), dan (perilaku) siswa.

Berdasarkan uraian di atas dan beberapa penelitian yang telah dilakukan, peneliti ingin mengetahui hubungan yang terjadi antara studentteacher trust dengan school well-being pada siswa SMA.

\section{METODE}

Jenis penelitian yang digunakan adalah penelitian kuantitatif, dengan jenis korelasional. Variabel pertama pada penelitian ini adalah studentteacher trust dan variabel lainnya adalah school well-being. Peneliti menggunakan teknik penyebaran kuesioner.

Skala student-teacher trust dibuat sendiri dengan mengacu pada teori yang dikemukakan oleh Tschannen-Moran (2014). Skala student-teacher trust terdiri dari 20 butir yang mengukur lima komponen dari trust. Contoh butir dari skala student-teacher trust seperti "guru saya peka terhadap kebutuhan siswanya". Dari hasil uji validitas dan reliabilitas, didapatkan 18 butir yang berfungsi dengan baik.

Skala school well-being diadaptasi oleh penulis yang mengaç pada teori yang dikemukakan oleh Konu dan Rimpelä (2002). Skala school wellbeing terdiri dari 53 butir yang mengukur empat dimensi dari school well-being. Contoh item dari skala school well-being seperti "saya merasa diperhatikan oleh guru di sekolah”. Dari hasil uji validitas dan reliabilitas, didapatkan 47 butir yang berfungsi dengan baik.

Partisipan penelitian ini adalah siswa Sekolah Menengah Atas (SMA) X di Jakarta Barat dan siswa SMA Y di Jakarta Utara dengan jumlah populasi adalah 486 siswa. Teknik sampling yang digunakan dalam penelitian ini merupakan teknik purposive.

Data demografis menunjukkan bahwa partisipan_pada penelitian ini berada pada usia 14 tahun (0.4\%), 15 tahun (25.3\%), 16 tahun (28.6\%), 17 tahun (39.1\%), dan 18 tahun (6.2\%). Penelitian ini menggunakan subyek degan jenis kelamin laki-laki berjumlah 238 orang $(49.0 \%)$ dan perempuan berjumlah 248 orang (51.0\%). Selain itu, partisipan pada penelitian ini merupakan siswa SMA yang berada pada kelas $\mathrm{X}$ dengan jumlah 186 siswa (38.3\%), kelas XI dengan jumlah 108 siswa (22.2\%), dan siswa kelas XII sebanyak 192 siswa (39.5\%).

Analisis data yang dilakukan pada penelitian ini adalah uji korelasi, dan sebelumnya dilakukan uji normalitas sebaran data dengan menggunakan teknik Kolmogorov-smirnov.

\section{HASIL}

Hasil analisis korelasi antara student-teacher trust dengan school well-being menunjukkan $\mathrm{r}=0,551$ dan dinyatakan sangat signifikan. Dengan demikian dapat dinyatakan terdapat hubungan antara student-teacher trust
Deleted: a 
dengan school well-being. Hal ini berarti semakin tinggi student-teacher trust di sekolah $\mathrm{X}$ dan $\mathrm{Y}$ maka semakin tinggi pula school well-being yang dimiliki siswa pada kedua sekolah tersebut.

Hasil analisis korelasi selanjutnya antara student-teacher trust dengan dimensi school well-being diperoleh : (1) Dimensi having, loving, being, dan health dalam school well-being mempunyai hubungan positif dan signifikan dengan student-teacher trust. Dimensi having berkorelasi dengan $\mathrm{r}=$ 0.440 dengan $\mathrm{p}=0.000<0.05$ jadi terdapat hubungan positif dan signifikan; (2) Dimensi loving berkorelasi dengan $\mathrm{r}=0.527$ dengan $\mathrm{p}=$ $0.000<0.05$ jadi terdapat hubungan positif dan signifikan; (30 Dimensi being berkorelasi dengan $r=0.450$ dengan $\mathrm{p}=0.000<0.05$ jadi terdapat hubungan positif dan signifikan; (4) Dimensi health berkorelasi dengan $\mathrm{r}=$ 0.325, $\mathrm{p}=0.000<0.05$ jadi terdapat hubungan positif dan signifikan.

Uji korelasi tambahan terhadap skor total school well-being dan dimensi student-teacher trust, diperoleh hasil (1) Dimensi benevolence berkorelasi dengan $r=0.610$ dengan $p=0.000<$ 0.05 jadi terdapat hubungan positif dan signifikan; (2) Dimensi honesty berkorelasi dengan $\mathrm{r}=0.452$ dengan $\mathrm{p}=$ $0.00<0.05$ jadi terdapat hubungan positif dan signifikan; (3) Dimensi openness berkorelasi dengan $r=0.564$ dengan $\mathrm{p}=0.000<0.05$ jadi terdapat hubungan positif dan signifikan; (4) Dimensi reliability berkorelasi dengan $\mathrm{r}$ $=0.617$ dengan $\mathrm{p}=0.000<0.05$ jadi terdapat hubungan positif dan signifikan; dan (5) Dimensi competence berkorelasi dengan $\mathrm{r}=0.533$ dengan $\mathrm{p}=$ $0.000<0.05$ jadi terdapat hubungan positif dan signifikan.

Penelitian ini juga melakukan uji beda student-teacher trust yang ditinjau dari jenis kelamin dan uji beda school well-being yang ditinjau berdasarkan jenis kelamin juga. Berdasarkan uji beda yang telah dilakukan dengan menggunakan Independent Sample Ttest, didapatkan hasil yaitu kedua variabel tersebut (student-teacher trust dan school well-being) tidak terdapat perbedaan yang signifikan jika ditinjau berdasarkan jenis kelamin baik pada jenis kelamin laki-laki maupun perempuan.

\section{DISKUSI}

Penelitian ini mendapatkan hasil bahwa dimensi honesty pada studentteacher trust memiliki nilai mean empirik yang paling tinggi dibandingkan dengan dimensi yang lain. Hal ini membuktikan bahwa dengan guru memberikan penilaian terhadap siswanya dengan jujur, maka siswa akan cenderung untuk semakin percaya kepada gurunya. Selain itu, siswa juga akan cenderung untuk semakin percaya kepada gurunya saat guru memberikan informasi yang benar seperti tentang akademik siswanya kepada siswanya.

Penelitian ini juga menemukan hasil bahwa dimensi loving pada school well-being memiliki nilai mean empiric yang paling tinggi dibandingkan dengan dimensi yang lain. Hal ini berarti dengan adanya perhatian yang diberikan guru kepada muridnya dan guru menjawab pertanyaan para siswa dengan baik maka siswa akan semakin merasa nyaman untuk melakukan aktivitas di sekolah. Selain itu, school well-being juga akan semakin tergambarkan ketika siswa memiliki hubungan yang baik dengan teman-temannya dan siswa merasa senang untuk bertukar pikiran dengan temannya.

Hasil penelitian ini sejalan dengan pernyataan Cohen (dalam Mitchell, Kensler, \& Tschannen-Moran, 2016) yang menguraikan bahwa pengurus dan guru di sekolah memiliki kemampuan untuk memengaruhi faktor-faktor iklim sekolah, sehingga dapat menciptakan kenyamanan bagi siswa di sekolah. 
Hubungan yang baik antara siswa dengan guru dan teman-temannya juga memiliki peran yang penting dalam school well-being (Konu \& Rimpelä, 2002). Hubungan antara pengurus, guru, siswa, dan orangtua akan memengaruhi segala hal yang terjadi di sekolah. Ketika siswa merasa tidak aman dan tidak percaya terhadap gurunya maka siswa akan cenderung untuk tidak mengambil resiko sehingga dapat menyebabkan penurunan motivasi siswa dan siswa cenderung menarik diri baik secara fisik dan emosional (Mitchell, Kensler, \& TschannenMoran, 2016).

Persepsi siswa terhadap hubungan dengan gurunya dapat memengaruhi keterikatan siswa di sekolah dan wellbeing siswa (Hallinan, 2008; Van Petegem et al., dalam Maele \& Houtte, 2010). Persepsi siswa terhadap hubungan dengan guru dan pembelajaran di sekolah dipengaruhi oleh tingkat kepercayaan siswa terhadap gurunya (Tchannen-Moran, Mitra, Ennis dan McCauley dalam Maele \& Houtte, 2010). Hal ini menunjukkan bahwa persepsi siswa terhadap relasinya dengan guru akan berhbungan dengan keterlibatan siswa di sekolah, kepercayaan siswa terhadap gurunya, dan well-being siswa.

\section{SIMPULAN}

Berdasarkan hasil analisis data menunjukkan maka dapat disimpulkan bahwa ada hubungan positif dan signifikan antara student-teacher trust dan school well-being.

Berdasarkan hasil penelitian yang ada, peneliti mengajukan beberapa saran praktis yaitu siswa maupun guru sebaiknya semakin membangun kedekatan antara satu dengan juga yang lain dengan cara membuat proses belajar mengajar yang inovatif (menggunakan media, melakukan interaksi, dan kerjasama yang baik), menjadi guru yang kreatif dalam memberikan pelajaran, mendengarkan cerita (curhatan) siswa, dan memberikan motivasi sehingga semakin menimbulkan rasa percaya yang tinggi. Sekolah juga sebaiknya semakin memerhatikan kompetensi guru yang akan diberikan kepada siswa sehingga siswa akan semakin percaya kepada kemampuan mengajar guru yang ada di sekolahnya.

Saran berikutnya ditujukan kepada sekolah untuk menciptakan lingkungan yang aman, nyaman, dan bebas dari penyakit. Hal tersebut dapat dilakukan dengan cara mengembangkan budaya sekolah yang positif, membangun komunitas sekolah dengan cara saling menghargai dan adil, saling menghargai perbedaan yang ada, memonitor dan mengevaluasi lingkungan sekolah untuk peningkatan keamanan sekolah, meningkatkan disiplin siswa, menghilangkan adanya kekerasan di lingkungan sekolah, dan menanamkan rasa saling peduli satu dengan yang lain. Hal tersebut bertujuan agar segala aktivitas yang dilakukan di sekolah dapat berjalan dengan semakin kondusif.

\section{DAFTAR PUSTAKA}

Basch, C. A. (2012). Student-teacher trust relationship and student performance. Education Doctoral, 118, 1-145.

Byrk, A. S., \& Schneider, B. (2004). Trust in schools. New York, NY: Russell Sage.

Eres, F., \& Bilasa, P. (2016). Middle school students' perceptions of the quality of school life in Ankara. Journal of Education and Learning, 6(1), 175-183. Doi: 10.5539/jel.v6n1p175 
Hamidah, N. (2018, 19 Januari) Guru dan perilaku diskriminatif. Gurusiana.id. diunduh dari http://nurhamidah.gurusiana.id/a rticle/guru-dan-perilakudiskriminatif-4090440.

Ini 15 bentuk diskriminasi sekolah terhadap siswa versi KPAI. (2013, $01 \quad$ November). detiknews. Diunduh dari https://news.detik.com/berita/24 02128/ini-15-bentukdiskriminasisekolah-terhadapsiswa-versi-kpai.

Khatimah, H. (2015) Gambaran school well-being pada peserta didik program kelas akselerasi di SMA Negeri 8 Yogyakarta. Psikopedagogia. 4(1), 20-30.

Konu, A., \& Rimpelä, M. (2002). Wellbeing in schools: A conceptual model. Health Promotion International, 17(1), 79-87. Doi: https://doi.org/10.1093/heapro/1 7.1.79

Lee, S.J. (2007). The relations between the student-teacher trust relationship and school success in the case of Korean middle. Educational Studies, 33, 209216.

doi:10.1080/0305569060106847 7.

Lee, S.J. (2007). The relations between the student-teacher trust relationship and school success in the case of Korean middle. Educational Studies, 33, 209216.

doi:10.1080/0305569060106847 7.

Maele, D. V., \& Houtte, M. V. (2010). The Quality of School Life: Teacher-Student Trust Relationship School Context. doi: 1 0-1007/s 1 1205-0109605-8.
McEvoy, A. (2014). Abuse of power: Most bullying prevention is aimed at students. What happens when adults are the aggressors?. Teaching Tolerance.org. Retrieved from https://www.tolerance.org/maga zine/fall-2014/abuse-of-power.

Mitchell, R. M., Kensler, L., \& Tchannen-Moran, M. (2016). Student trust in teachers and student perceptions of safety: positive predictors of student identification with school. International Journal of Leadership in Education, 1-21. doi:

10/1080/13603124.20016.11572 11.

Taufiqurrahman. (2018, 03 Februari). Penganiayaan guru oleh siswa di Sampang, begini kronologinya. KOMPAS.com. Diunduh dari https://regional.kompas.com/rea d/2018/02/03/10041991/pengani ayaanguru-oleh-siswa-

disampang-begini-kronologinya.

Tian, L., Liu, B., Huang, S., \&Huebner, E. S. (2012). Perceived social support and school well-being among Chinese early and middle adolescents: the mediational role of self-esteem. Social Indicator Research, 113, 991-1008. doi:10.1007/s11205012-0123-8.

Tschannen-Moran, M. (2014), Trust matters: leadership for successful schools (2nd ed.). California, CA: Jossey-Bass. 